\title{
The Orograpic Effects on Precipitation Distribution in Tirol, Austria
}

\author{
Takayoshi Aoyama*
}

\begin{abstract}
Meterological conditions for the occurrences of precipitation distribution pattern in Tirol, Austria, and the orograpaphic effects on it were examined on the bases of the 250 daily precipitation maps in 1956 and 1957. The distributions of the precipitation amount were classified into four main types. They show the apparent orographic effects such as the blocked effect, the rain shadow effect and the effect to make orographic rain bands. The meteorological conditions were investigated through analyses on the weather situation, the stability of lower layer and wind aloft. The results reveal that the blocked and rain shadow effects are predominant in the relatively stable stratification under the upper wind direction with larger north or south components; and on the contrary, rain band tends to form under unstable conditions.

In order to show the geographical distribution of these orographic effects, the occurrence frequency of the daily precipitation amount above $10 \mathrm{~mm} /$ day was counted by setting $10 \mathrm{~km} \times 10 \mathrm{~km}$ grids over the study area. The regional division based on the orographic effects were made with reference to this geographical distribution of frequency. The geographical distribution of rain band axes was also demonstrated for heavy rain days in the years of 1948 to 1957 . It was found that the northern Alps accounts for the significant blocked and rain shadow effects while Etschtal the effects to form rain band.
\end{abstract}

\section{Introduction}

In a previous paper (Aоунма, 1985), the author has described the geographical distribution of weather divide and the synoptic conditions for its occurrence in Tirol. The precipitation distribution maps were, taking the occurrence of weather divide into consideration, classified into four distribution patterns. Weather situation, wind aloft, convective instability and condensation level for each precipitation distribution pattern were analysed in order to show the synoptic conditions of the weather divide occurrence. In that study, it was pointed out that each precipitation pattern, and also the weather divide, occur under the characteristic meteorological conditions and the location of the maximum frequency of the weather divide varies with both the components of meterological and orographic conditions.

Regarding the precipitation distribution in the Alps region, FLIRI (1974a, 1982, 1983) studied it in connection with the weather situations. In these studies he showed the characteristic precipitation patterns under each weather situation. In particular, the orographic effects in Tirol or in the neighbouring region have been investigated by FLOHN (1954), WAGNer (1964) and Fliri (1967, 1969, 1974b).

In this paper, the author investigates the precipitation distribution patterns and the synoptic conditions for their occurrences and further shows the orographic effects on precipitation distribution in Tirol.

\section{Classification of daily precipitation maps}

This study is conducted on the basis of the precipitation maps which were used in the previous paper (Aоyama, 1985). The data for these maps are the daily precipitation amount recorded at 189 weather stations in Austria, Italy, Germany and Switzerland. The study area covers latitude $46^{\circ} 10^{\prime} \mathrm{N}$ to $47^{\circ} 30^{\prime} \mathrm{N}$ and

* Faculty of General Education, Yamagata University, Koshirakawa, Yamagata 990, Japan. 


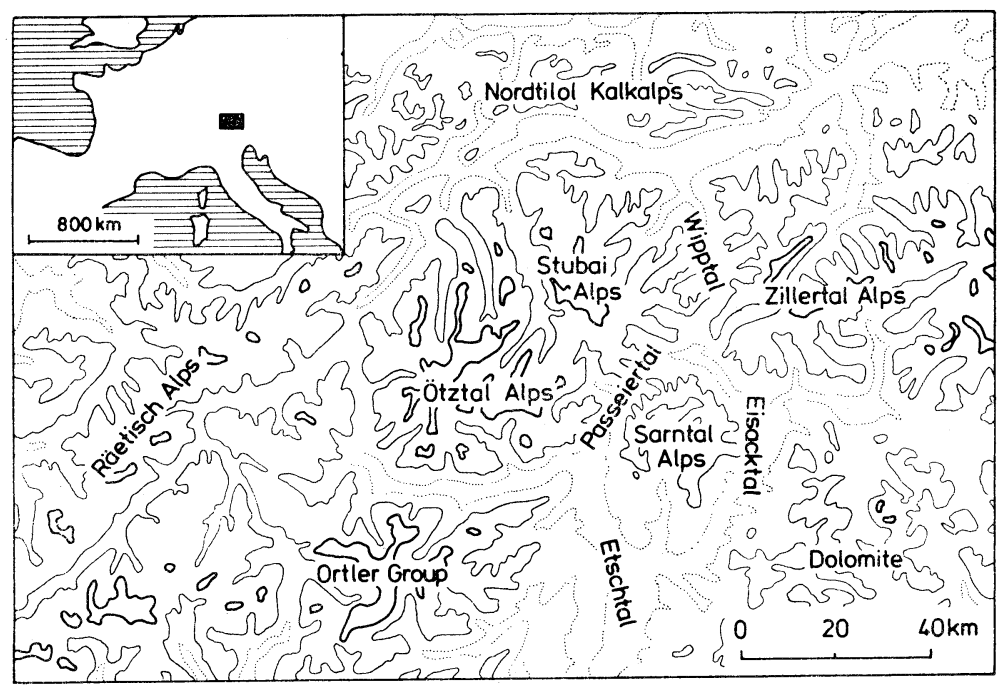

Figure 1. Index map.

Contours indicate $1000 \mathrm{~m}, 2000 \mathrm{~m}$ and $3000 \mathrm{~m}$ above sea level.

longitude $9^{\circ} 30^{\prime} \mathrm{E}$ to $12^{\circ} 50^{\prime} \mathrm{E}$, and the extent is about $35,000 \mathrm{~km}^{2}$ (Figure 1). All the data used in this study were provided from Prof. Dr. F. FLIRI of Innsbruck University.

Two hundred and fifty daily precipitation maps were prepared for the days in 1956 and 1957 on which precipitation was reported at more than ten stations. These maps were classified into four main types (Type I-IV), taking the relation between the location of rain area and mountain chains into account. These main types were further subdivided into eight

Table 1. Occurrence frequency (days) of the precipitation distribution pattern.

\begin{tabular}{|c|c|c|c|c|c|c|}
\hline & Type & $\begin{array}{l}\text { Winter } \\
\text { (D.-F.) }\end{array}$ & $\begin{array}{c}\text { Spring } \\
\text { (M.-M.) }\end{array}$ & $\begin{array}{l}\text { Summer } \\
\text { (J.-A.) }\end{array}$ & $\begin{array}{l}\text { Autumn } \\
\text { (S.-N.) }\end{array}$ & Total \\
\hline \multirow[t]{3}{*}{ I } & $\mathrm{a}$ & 23 & 17 & 15 & 17 & 72 \\
\hline & $\mathrm{b}$ & 0 & 2 & 6 & 1 & 9 \\
\hline & Total & 23 & 19 & 21 & 18 & 81 \\
\hline \multicolumn{2}{|l|}{ II } & 1 & 9 & 10 & 8 & 28 \\
\hline \multirow[t]{3}{*}{ III } & $\mathrm{a}$ & 5 & 10 & 0 & 4 & 19 \\
\hline & $\mathrm{b}$ & 3 & 7 & 7 & 11 & 28 \\
\hline & Total & 8 & 17 & 7 & 15 & 47 \\
\hline \multirow[t]{4}{*}{ IV } & $\mathrm{a}$ & 0 & 6 & 35 & 5 & 46 \\
\hline & $\mathrm{b}$ & 0 & 2 & 11 & 2 & 15 \\
\hline & $\mathrm{c}$ & 0 & 4 & 10 & 0 & 14 \\
\hline & Total & 0 & 12 & 56 & 7 & 75 \\
\hline \multicolumn{2}{|c|}{ Unclassifiable } & e 1 & 6 & 6 & 6 & 19 \\
\hline \multicolumn{2}{|r|}{ Total } & 33 & 63 & 103 & 51 & 250 \\
\hline
\end{tabular}

basic patterns. The seasonal frequency of these types are shown in Table 1.

Kawamura $(1961,1964)$ studied the synoptic climatology of winter monsoon in Japan on the basis of the percentage frequency of days with daily precipitation more than $5 \mathrm{~mm}$. In these studies, he showed a detailed weather distribution and the topographic influence under various airflow patterns. In order to obtain the distribution patterns of precipitation and topographic effects in Tirol, the occurrence frequency of the daily precipitation amount above $10 \mathrm{~mm} /$ day were counted by setting $10 \mathrm{~km} / 10 \mathrm{~km}$ grids over the study area. Namely, the frequency is the number of times when the portion with the precipitation above $10 \mathrm{~mm} /$ day occupies over a half of given grid. The distributions of these frequency were made for the four respective precipitation patterns and their geographical distributions are shown in Figures 2, 3, 4 and 5.

Type $I$ is the distribution pattern that can be called the north blocked (by the mountain) type $^{1)}$ as shown in Figure 2. This type is subdivided into two basic types of Ia and Ib. Type Ia has the typical feature of the north blocked type. Type Ib has almost the same feature but with irregular isohyets pattern, especially in the southern side of the main watershed.

Type I occurs at a frequency of $32 \%$ among 


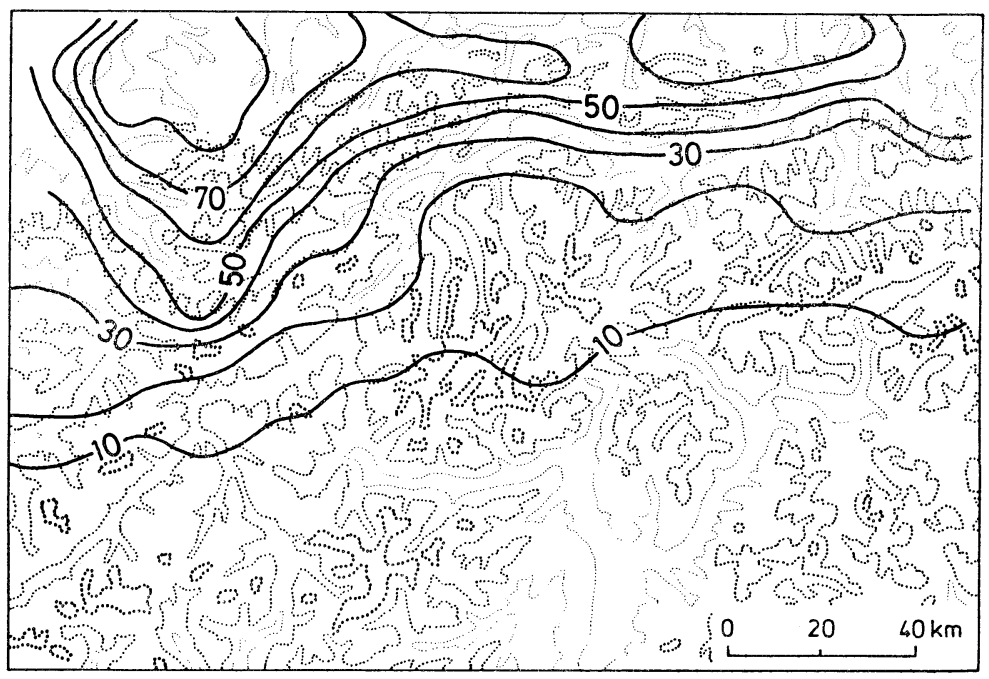

Figure 2. Precipitation distribution pattern of the north blocked type (Type I).

Contours show the percentage frequency of the days with daily precipitation more than $10 \mathrm{~mm}$ in the case of Type I. Contour interval is $10 \%$.

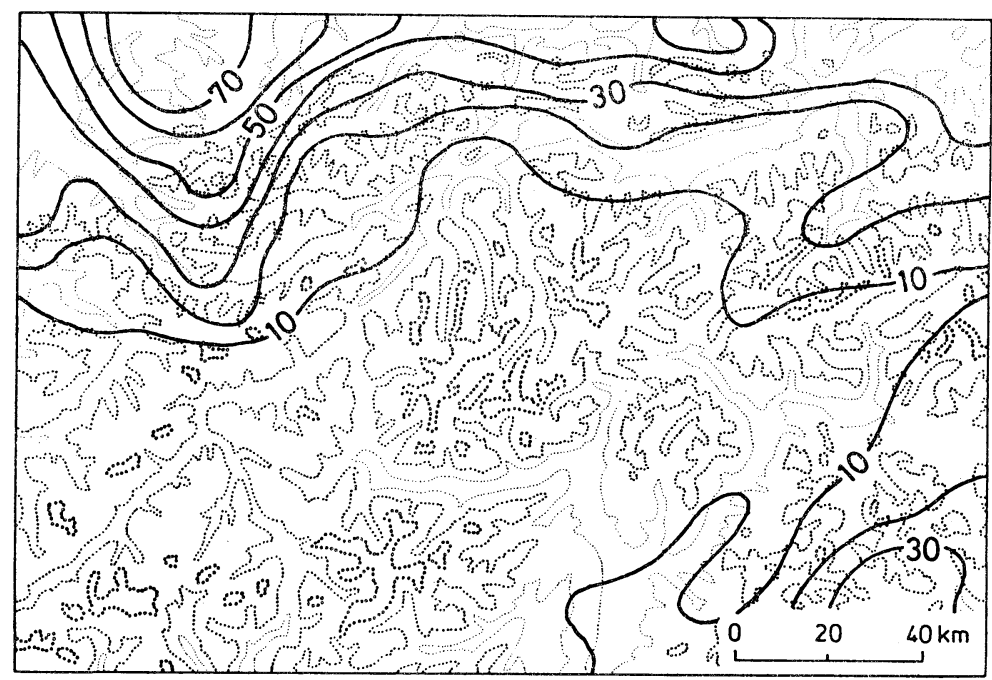

Figure 3. Precipitation distribution pattern of the transitional type (Type II).

Same as in Figure 2 except in the case of Type II.

all cases and no distinct seasonal change is recognized. The occurrence of Type Ia, however, shows a seasonal change with the maximum frequency (32\% of this type) in winter (December-February) and minimum (21\%) in summer (June-August).

Type II is the distribution pattern that can be considered to be the mixed or transitional pattern between Type I and III as shown in Figure 3. This type occurs at a frequency of $11 \%$ of all cases and mainly in summer, spring and autumn.

Type III is the distribution pattern (Figure 4) that can be called the south blocked type. This type is subdivided into two types, IIIa and IIIb. Since Type IIIa has the typical 


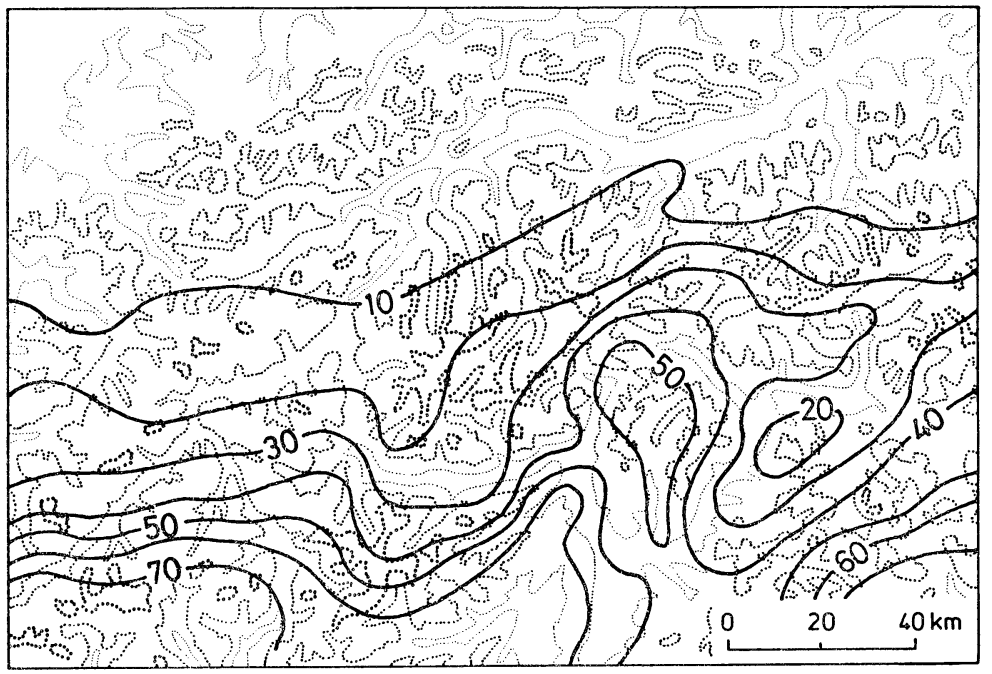

Figure 4. Precipitation distribution pattern of the south blocked type (Type III).

Same as in Figure 2 except in the case of Type III.

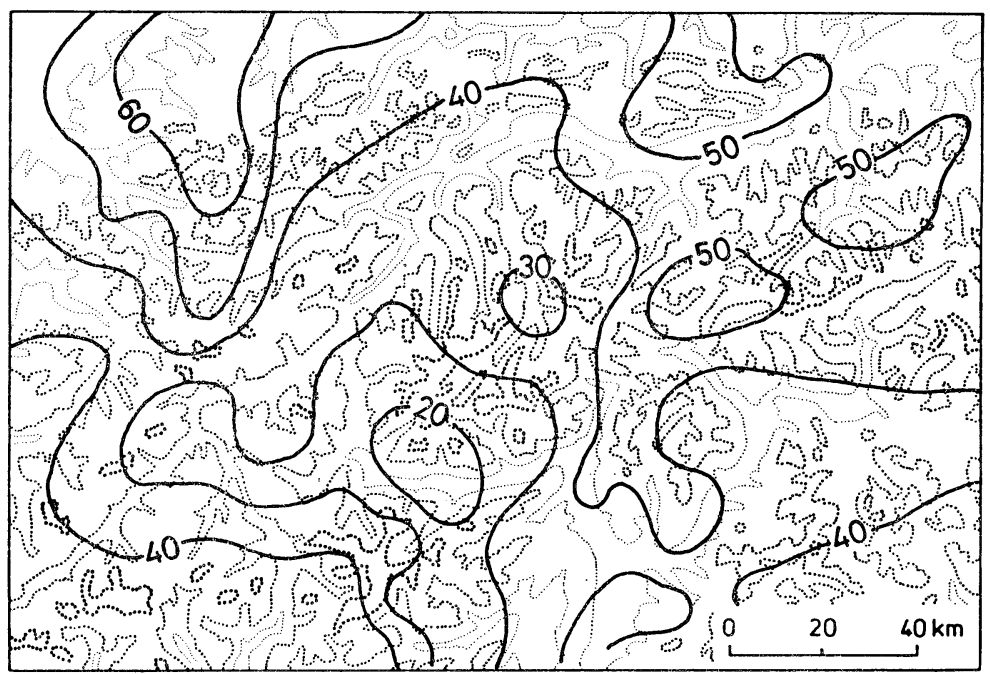

Figure 5. Precipitation distribution pattern of the whole-area rain type (Type IV).

Same as in Figure 2 except in the case of Type IV.

feature of precipitation distribution under the condition of the strong south-Föhn as indicated by FLIRI (1983), this type can also be called Föhn type. Type IIIb bears the same feature on the whole but the rain area reaches the northern side of the Alps with an irregular isohyet pattern.

Type III appears at a frequency of $19 \%$ and has the relatively high frequency in spring
(March-May) and autumn (September-November).

Type IV is the pattern that can be called the whole-area rain type as shown in Figure 5. This type is subdivided into three types, IVa, $\mathrm{IVb}$ and IVc, according to the running direction of isohyets. Type IVa has the isohyets running in the direction of SW-NE, Type IVb $\mathrm{S}-\mathrm{N}$ and Type IVc $\mathrm{W}-\mathrm{E}$, respectively. 
Type IV occurs the most frequently (38\%) in all cases and the occurrences concentrate in summer at a frequency of $66 \%$ of this type.

These patterns mentioned above suggest the remarkable effects of topography, for instance, the blocked and the rain shadow effect. In the case of Type I and Type III, these orographic effects are prominent. In the case of Type IV, the remarkable effects can also be recognized. That is, the precipitation distribution of Type IV is frequently accompanied with a rain band; the rain bands have a tendency to occur at fixed locations.

The above defined precipitation days show the clear seasonal change in the occurrence frequency; the maximum frequency (41\%) in summer and the minimum frequency $(13 \%)$ in winter. Moreover, each precipitation distribution pattern shows also the characteristic seasonal change of occurrences. The north blocked type (Type I) tend to occur in winter, the south blocked type or the Föhn type (Type III) in spring and autumn and the whole-area rain type (Type IV) in summer.

\section{Synoptic conditions for each precipitation distribution pattern}

In the previous paper (Aoyama, 1985), the wind aloft and stability in the lower layer at München and the weather situation by the modified Lauscher's scheme ${ }^{2}$, which was reported by FLIRI (1962), have been examined in order to clarify the synoptic conditions for the occurrence of weather divide. In this chapter the synoptic conditions for each precipitation pattern will be reexamined on the bases of the aerological data collected at Payerne in Switzerland and the classification of weather situations by SchüEPP and HÄFELIN (1956, 1957).

1) Weather situation

The frequency of weather situations based on the ScHüEPP's scheme for each precipitation pattern were obtained from "Wetterlagen und Fronten im Jahr 1956, 1957" by ScHüEPP and HÄFELIN $(1956,1957)$. The frequency of weather situations which are related to the occurrences of each precipitation pattern are shown in Table 2.

Types I and III of precipitation pattern
Table 2. Occurence frequency (days) of the weather situations by ScHüEPP and HÄFELIN (1956, 1957) for each precipitation distribution pattern. Figures in parentheses represent percentage frequency of each precipitation distribution Type.

\begin{tabular}{|c|c|c|c|c|}
\hline Weather situation & I & II & III & IV \\
\hline Bise & $13(16.0)$ & $3(10.7)$ & $1(2.1)$ & $0(0.0)$ \\
\hline Stau & $20(24.7)$ & $4(14.3)$ & $0(0.0)$ & $3(4.0)$ \\
\hline $\mathrm{W}$ wind & $14(17.3)$ & $2(7.1)$ & $0(0.0)$ & $6(8.0)$ \\
\hline Föhn & $0(0.0)$ & $1(3.6) 2$ & $20(42.6)$ & $2(2.7)$ \\
\hline $\begin{array}{r}\text { War } \\
\text { ad }\end{array}$ & ) & $(0.0)$ & $1(2.1)$ & $3(4.0)$ \\
\hline Cont & $2(2.5)$ & $1(3.6)$ & $2(4.3)$ & $7(9.3)$ \\
\hline Cold air advection & $8(9.9)$ & $4(14.3)$ & $2(4.3)$ & $2(2.7)$ \\
\hline $\begin{array}{l}\text { Uppe } \\
\text { ant }\end{array}$ & $6(7.4)$ & $2(7.1)$ & $0(0.0)$ & 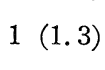 \\
\hline $\begin{array}{r}\text { Uppe } \\
\text { cyc }\end{array}$ & $0(0.0)$ & $1(3.6)$ & $8(17.0)$ & $9(12.0)$ \\
\hline $\begin{array}{l}\text { Indet } \\
\text { upp }\end{array}$ & $11(13.6)$ & $5(17.9)$ & $8(17.0) 3$ & $36(48$. \\
\hline Others & $5(6.2)$ & $5(17.9)$ & $5(10.6)$ & $6(8.0)$ \\
\hline
\end{tabular}

mainly occur under the weather situations with strong winds. Fiftyeight percent of Type I occur under the weather situations of "Stau, W wind and Bise"3) and about $43 \%$ of Type III occur under that of "Föhn". The occurrence of Type IV concentrates under "Undeterminate upper flow" (48\%). According to the classification of weather situations based on the Lauscher's scheme, Type I tends to occur under the "extensive upper airflow situations," "W) W and NW situation, Type III under the "Low pressure margin situations," TB and TwM situation, and Type IV under the "Low pressure margin" and the "Low pressure situation" (Aoyama, 1985).

2) Upper wind direction

The wind direction at the level of $500 \mathrm{mb}$ is investigated on the basis of the aerological data collected at Payerne $\left(6^{\circ} 57^{\prime} \mathrm{E}, 46^{\circ} 49^{\prime} \mathrm{N}\right.$, $491 \mathrm{~m}$ a.s.1.) in Switzerland (AckermanN, 1956, 1957). The observation were made two times a day; the observation time were at 3.00 MET (Middle European Time) and 15.00 MET till March, 1957 and at 0.00 MET and 12.00 MET from April, 1957. The frequency of wind direction are made from these data for each precipitation distribution pattern; the frequency at 15.00 MET (or at 12.00 MET) is counted as one and that at 3.00 MET (or 0.00 MET) on that 
Table 3. Occurrence frequency of wind direction at the $500 \mathrm{mb}$ level over Payerne, Switzerland for each precipitation distribution pattern. Figures in parentheses represent percentage frequency.

\begin{tabular}{|c|c|c|c|c|c|c|c|c|c|c|c|}
\hline & \multicolumn{3}{|c|}{ I } & \multirow{2}{*}{ II } & \multicolumn{3}{|c|}{ III } & \multicolumn{4}{|c|}{ IV } \\
\hline & a & $\mathrm{b}$ & total & & $\mathrm{a}$ & $\mathrm{b}$ & total & $\mathrm{a}$ & $\mathrm{b}$ & $\mathrm{c}$ & total \\
\hline $\mathrm{E}$ & 0.0 & 0.0 & $0.0(0.0)$ & $2.5(5.2)$ & 0.5 & 2.0 & $2.5(2.7)$ & 0.0 & 0.0 & 0.0 & $0.0(0.0)$ \\
\hline ENE & 0.0 & 0.0 & $0.0(0.0)$ & $1.0(2.1)$ & 1.0 & 0.0 & $1.0(1.1)$ & 0.0 & 0.0 & 0.0 & $0.0(0.0)$ \\
\hline $\mathrm{NE}$ & 3.5 & 0.0 & $3.5(2.2)$ & $3.0(6.3)$ & 0.5 & 1.5 & $2.0(2.2)$ & 0.0 & 1.0 & 0.5 & $1.5(1.0)$ \\
\hline NNE & 7.0 & 0.0 & $7.0(4.4)$ & $1.5(3.1)$ & 0.5 & 1.0 & $1.5(1.6)$ & 0.0 & 0.0 & 0.0 & $0.0(0.0)$ \\
\hline $\mathrm{N}$ & 26.0 & 0.0 & $26.0(16.3)$ & $3.0(6.2)$ & 0.5 & 2.5 & $3.0(3.2)$ & 1.0 & 0.0 & 0.5 & $1.5(1.0)$ \\
\hline NNW & 24.0 & 0.0 & $24.0(15.0)$ & $5.0(10.4)$ & 0.0 & 1.0 & $1.0(1.1)$ & 1.5 & 1.5 & 2.0 & $5.0(3.4)$ \\
\hline NW & 31.0 & 1.5 & $32.5(20.3)$ & $4.5(9.4)$ & 0.0 & 2.0 & $2.0(2.2)$ & 1.5 & 1.0 & 2.5 & $5.0(3.4)$ \\
\hline WNW & 20.5 & 2.5 & $23.0(14.4)$ & $8.5(17.7)$ & 0.0 & 1.0 & $1.0(1.1)$ & 5.5 & 0.0 & 1.0 & $6.5(4.5)$ \\
\hline W & 17.0 & 4.0 & $21.0(13.1)$ & $9.0(18.8)$ & 0.5 & 7.5 & $8.0(8.6)$ & 29.0 & 3.5 & 7.0 & $39.5(27.1)$ \\
\hline WSW & 4.5 & 3.0 & $7.5(4.7)$ & $2.5(5.2)$ & 2.5 & 6.5 & $9.0(9.7)$ & 23.5 & 2.0 & 8.5 & $34.0(23.3)$ \\
\hline SW & 7.0 & 2.5 & $9.5(5.9)$ & $3.5(7.3)$ & 10.5 & 10.0 & $20.5(22.2)$ & 17.0 & 7.5 & 3.0 & $27.5(18.8)$ \\
\hline SSW & 2.0 & 0.5 & $2.5(1.6)$ & $2.5(2.5)$ & 7.0 & 3.0 & $10.0(10.8)$ & 7.5 & 3.5 & 0.0 & $11.0(7.5)$ \\
\hline S & 0.0 & 1.0 & $1.0(0.6)$ & $0.0(0.0)$ & 12.0 & 11.5 & $23.5(25.4)$ & 3.5 & 2.5 & 2.0 & $8.0(5.5)$ \\
\hline SSE & 0.0 & 1.0 & $1.0(0.6)$ & $0.0(0.0)$ & 1.0 & 3.5 & $4.5(4.9)$ & 1.0 & 2.0 & 0.0 & $3.0(2.1)$ \\
\hline $\mathrm{SE}$ & 0.5 & 0.0 & $0.5(0.3)$ & $0.0(0.0)$ & 0.0 & 0.0 & $0.0(0.0)$ & 0.0 & 0.0 & 0.0 & $0.0(0.0)$ \\
\hline ESE & 0.0 & 0.0 & $0.0(0.0)$ & $1.5(3.1)$ & 1.5 & 1.5 & $3.0(3.2)$ & 2.0 & 0.5 & 0.0 & $2.5(1.7)$ \\
\hline
\end{tabular}

Table 4. Occurrence frequency of potential equivalent temperature difference (K) between $500 \mathrm{mb}$ and $850 \mathrm{mb}$ level (convective instability) at Payerne, Switzerland for each precipitation distribution pattern. Figures in parentheses represent percentage frequency.

\begin{tabular}{ccccccccccc}
\hline \hline \multirow{2}{*}{ Type } & \multicolumn{10}{c}{$\Delta \theta_{e}(500 \mathrm{mb}-850 \mathrm{mb}), \mathrm{K}$} \\
\cline { 2 - 9 } & \multicolumn{2}{c}{-15} & -9 & -3 & 3 & & 9 & 15 & 21 & 27 \\
\hline \multirow{2}{*}{ I } & & & 6.0 & 33.5 & 46.5 & 44.0 & 23.0 & 6.5 & 1.5 \\
& & & $(3.7)$ & $(20.8)$ & $(28.9)$ & $(27.3)$ & $(14.3)$ & $(4.0)$ & $(0.9)$ \\
II & & 0.5 & 2.0 & 13.0 & 17.5 & 15.5 & 4.0 & 1.0 & \\
& & $(0.9)$ & $(3.7)$ & $(24.3)$ & $(32.7)$ & $(29.0)$ & $(7.5)$ & $(1.9)$ & \\
III & 1.0 & 3.5 & 19.0 & 39.0 & 20.5 & 11.0 & & \\
& & $(1.1)$ & $(3.7)$ & $(20.2)$ & $(41.5)$ & $(21.8)$ & $(11.7)$ & & \\
IV & 1.0 & 4.0 & 8.0 & 48.5 & 55.0 & 20.5 & 5.0 & \\
& $(0.7)$ & $(2.8)$ & $(3.5)$ & $(34.4)$ & $(39.0)$ & $(14.5)$ & $(3.5)$ & \\
\hline
\end{tabular}

day and on the following day as 0.5. Namely, the total frequency on the given day doubled.

In the case of Type I, the frequency of the wind direction concentrate on the NW quadrant; the maximum frequency occurs in the direction of NW. Between the frequency distributions under Types Ia and Ib, some differences are recognized. Type Ia tends to occur under the wind with large north component, in the direction of NW, NNW and N, and Type $\mathrm{Ib}$ under the wind with a west component, in that of $\mathrm{W}$ and WNW.

In the case of Type III, the frequency concentrate on the wind direction of S, SW and SSW. No distinct difference is recognized between the frequency distribution of wind direction under Types IIIa and IIIb.

In the case of Type IV, the frequency con- centrates on the intermediate directions, W, WSW and SW, between Types I and III. Under Types IVa and IVc, the frequency distributions of the wind direction are almost the same but under Type IVb, slight differences are recognized; the mode of frequency is inclined towards the south in the case of Type IVb.

In the case of Type II, the feature of frequency distribution is almost the same as Type I but the mode of frequency tends to shift towards the west.

3) Convective instability

In the previous papers (Аоуама, 1984, 1985), it was shown that the stability of the lower layer in the troposphere is an important component causing the occurrence of the precipitation distribution pattern. In order to re- 
examine this, the convective instability in the lower layer were calculated from the data collected at Payerne (Ackermann, 1956, 1957); the convective instability were obtained as the difference between the potential equivalent temperature at the levels of $500 \mathrm{mb}$ and 850 $\mathrm{mb}$. The frequency distributions of the convective instability are made for each precipitation pattern by the same method as the wind direction (Table 4).

Although the maximum frequency of the convective instability for respective precipitation patterns fall into the class interval of $3 \mathrm{~K}$ $-9 \mathrm{~K}$, the ranges of these frequency are different from each other as in Table 4. For instance, the total frequency above $9 \mathrm{~K}$ are $46.5 \%$ in the case of Type I, 38.4\% in Type II, $33.5 \%$ in Type III and $18.0 \%$ in Type IV. On the other hand, the total frequency below $3 \mathrm{~K}$ are $24.5 \%$ in Type I, $28.9 \%$ in Type II, $25.0 \%$ in Type III and 41.4\% in Type IV. These results indicate that Type I, III and IV occur under the most stable, intermediate and most unstable conditions, respectively.

The synoptic conditions for the occurrence of each precipitation distribution pattern were examined by mean of the weather situation, wind direction aloft and convective instability. As a result, it was found that the respective precipitation distribution patterns occur under the characterristic synoptic conditions.

Type I and III, which show the remarkable blocked and rain shadow effects, occur under the condition of relatively stable air layer than that for type IV; stratification of air layer on the occasion of Type I are more stable than that of Type III. The same result has already been revealed in the studies for Kanto district in Japan and for Titol (Aoyama, 1984, 1985). Between Type I and Type III, however, weather situation and wind direction aloft are quite different. Type I occurs under the weather situations of the "Stau, Westerly winds and Bise" with wind directions of NW quadrant at the $500 \mathrm{mb}$ level. On the contrary, Type III occurs under the weather situation of "Föhn" with wind directions S, SSW and SW at the $500 \mathrm{mb}$ level. According to the classification of weather situation based on the LaUscher's scheme, Type III prevails under the weather situation of "Low pressure margin situation". This suggests that these southerly winds have the properties of cyclonic flow.

Type IV which is frequently accompanied with rain bands occurs under the condition of the most unstable layer and the weather situation of "Indeterminate upper flow". According to the LAUSCHER's scheme, this type tends to occur under the weather situation of "low pressure margin situation" or "low pressure situation". On the occasion of Types IVa, $I V c$ and II, in which the rain area spreads over both sides of the main mountain chain, winds at $500 \mathrm{mb}$ level blow from the intermediate directions, W and WSW, between Types I and III under relatively unstable condition. Type $\mathrm{IVb}$, however, occurs under the similar condition to that for type III; this occurs under the southerlies with cyclonic properties.

\section{Orographic effects on precipitation distribution}

FLOHN (1954) investigated the topographic effects on weather distribution in central Europe under the various weather situations and showed the geographical distribution of blocked and Föhn-region by southwesterlies and by northwesterlies. WACNER (1964) studied precipitation distribution in Baden-Würtemberg, Germany, and showed the regional distributins of blocked and lee-effect under the various weather situations.

From the four patterns of precipitation distributions, three kinds of orographic effects were suggested as described previously. These effects are blocked effect, rain shadow effect and the effect to make the rain band. Blocked and rain shadow effects are conspicuous in Types I and III. The rain band becomes clear in the case of Types IV and III as well. In the following, the geographical distribution of these orographic effects will be examined.

1) Blocked and rain shadow effects in Type I and Type III

In the case of precipitation distribution patterns of Types I and III, the clear weather divide which was defined by the isohyet of $1 \mathrm{~mm} /$ day appears along the main watershed in the study area as shown in Figures 6 and 9 (Aoyama, 1985). In the case of Type I, the weather divide indicates the southern limit 
and in the case of Type III, it indicates the northern limit of the weather with precipitation above $1 \mathrm{~mm} /$ day. Although these weather divides can be considered to be showing a relatively strong rain shadow effect, this must begin to operate from far windward mountains.

Here, blocked and rain shadow effects were defined by the gradient of the frequency of precipitation amount above $10 \mathrm{~mm} /$ day along the prevailing wind direction. Namely, the increase and the decrease of precipitation frequency in the direction of upper wind were considered as the blocked and the rain shadow

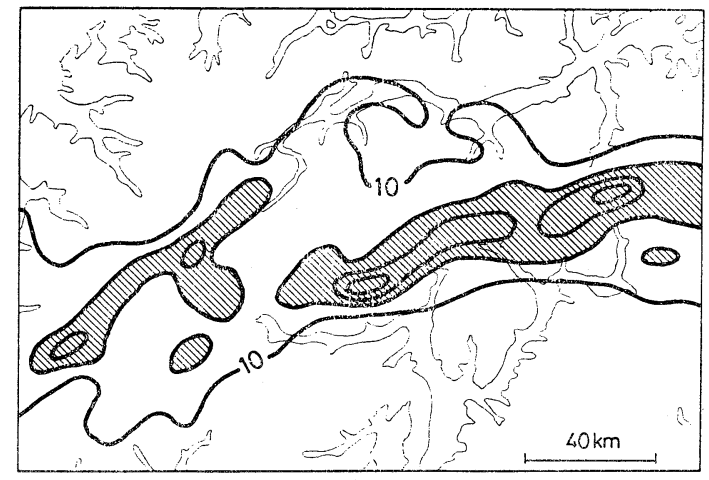

Figure 6. Distribution of occurrence frequency of weather divide in the case of Type I (AOYAMA, 1985).

Weather divide is defined by the isohyet of $1 \mathrm{~mm} /$ day. Contour interval is $10 \%$ and pattern of hatch indicates occurrence frequency above $10 \%$.

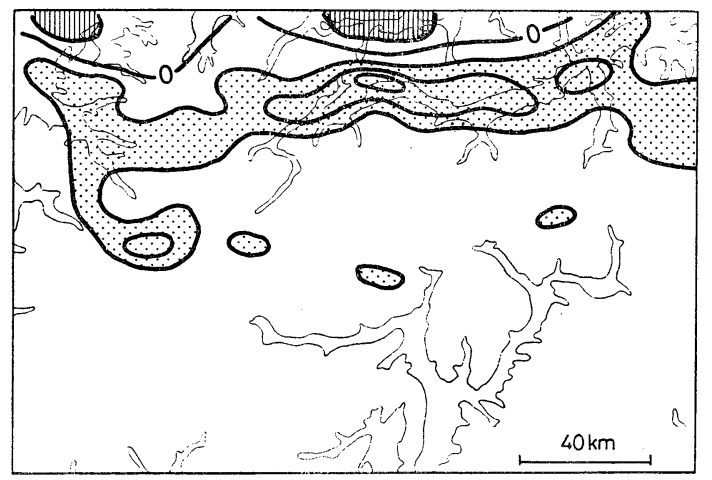

(a) effect respectively. In order to show the geographical distribution of blocked and rain shadow effects, the differences of precipitation frequency between adjacent grids are made from the same data as shown in Figure 2 and Figure 4 ; the meridional and zonal components of these differences per $10 \mathrm{~km}$ distance are evaluated and the geographical distribution are shown in Figure 7(a), (b) and Figure 10(a), (b). On the basis of these maps which dedemonstrate the difference of frequency or, in other words, frequency gradient regional classification were made for Type I (Figure 8) and Type III (Figure 11).

A) Type I In the case of Type I, the weather divide runs along the watershed of the main mountain chain, Zillertal Alps, Ötztal Alps and Rätisch Alps (Figure 6). In the region of the southern side of this weather divide, the weather without precipitation due to the rain shadow effect predominates in Type I.

As shown in Figure 7(a), the precipitation frequency increases from north to south in the north of and from south to north in the south of Nordtirol Kalkalps. On the other hand, the frequency from west to east increases in the western end of the study area, Vorarlberg, and decreases eastward (Figure 7(b)). In this case, since the prevailing winds blow from the northwest quadrant, $\mathrm{N}, \mathrm{NNW}, \mathrm{NW}, \mathrm{WNW}$ and $\mathrm{W}$, the increase and the decrease of these components of frequency differences indicate the

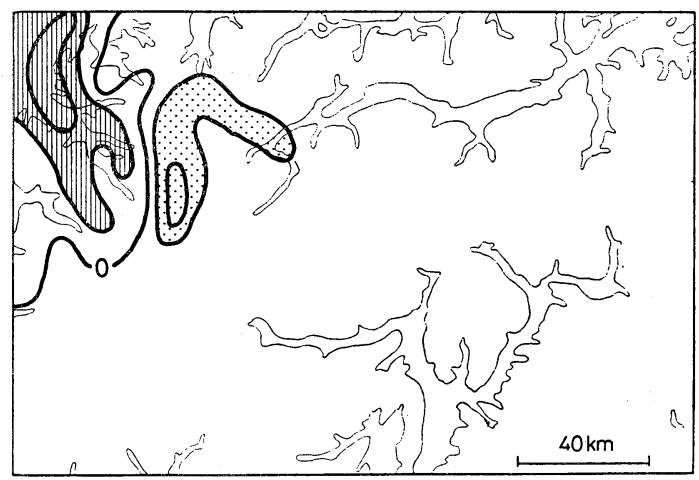

(b)

Figure 7. Meridional (a) and zonal (b) gradients of precipitation frequency in the case of Type I.

Meridional and zonal gradients are the north-south and west-east differences of the precipitation frequency per $10 \mathrm{~km}$ distance. Hatched pattern indicates increase of frequency from north to south in the meridional component (a) and from west to east in the zonal component (b). Dotted pattern shows decrease of frequency more than $10 \% / 10 \mathrm{~km}$ from north to south in the meridional component (a) and from east to west in the zonal component (b). Contour interval is $10 \% /$ $10 \mathrm{~km}$. 


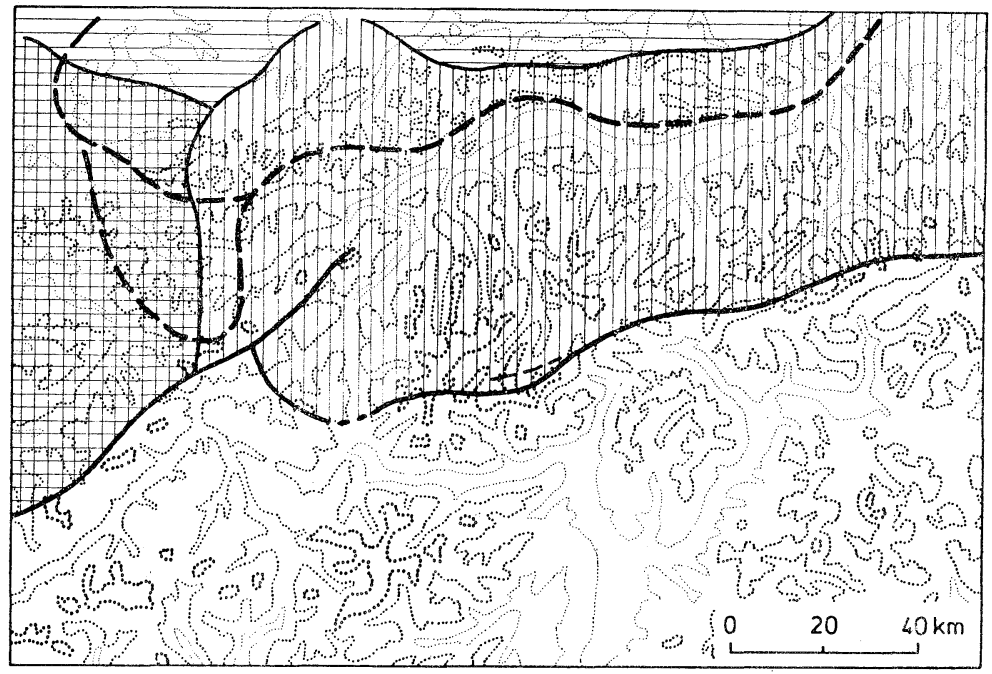

Figure 8. Regional division by orographic effects in the case of Type I.

Patterns of horizontal hatch, vertical hatch and mesh indicate blocked effect, rain shadow effect and mixed effect (influenced by both effects) region respectively. Heavy solid line indicates weather divide and heavy dashed lines indicate maximum orographic effect.

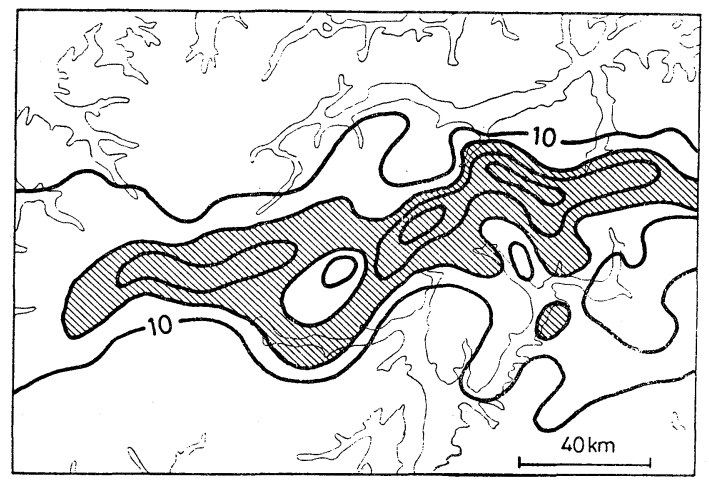

Figure 9. Distribution of occurrence frequency of weather divides in the case of Type III (AOYAMA, 1985).

Same as in Figure 6 except in the case of Type III.

blocked and the rain shadow effects as defined above, respectively. The isoline of zero demonstrates border line between the blocked effect and rainshadow effect regions.

From these maps of weather divide and the orographic effects, regional classification was made for Type I as shown in Figure 8. The southern limit of the region where the blocked effect can be recognized lies along a line just over the northern watershed of Nordtirol Kalkalps in the eastern part and further wind- ward of the watershed in the western part of the study area. In the drainage basin of River Inn in Tirol, conspicuous rain shadow effect can be recognized. In Vorarlberg, the western end of the study area, rain shadow effect prevails in northerlies and blocked effect in westerlies.

The line of the maximum orographic effects which were defined as the maximum gradient of precipitation frequency runs zonally along the southern ridges of the Nordtirol Kalkalps in the eastern part and meridionally almost along the border between Vorarlberg and Tirol.

B) Type III In the case of Type III, the weather divide tends to run on the slight leeward of the watershed of the main mountain chain (Figure 9). On the northern side of this weather divide, there is no precipitation.

The distribution of meridional and zonal components of frequency gradients are shown in Figure 10(a), (b). Since the prevailing winds blow from the SW, SSW and S, the blocked and rain shadow effect can be defined by the meridional component of frequency gradient. In this case, the increase and the decrease of the precipitation frequency from south to north is defined as the blocked and the rain shadow effects, respectively.

On the basis of these maps, regional division 


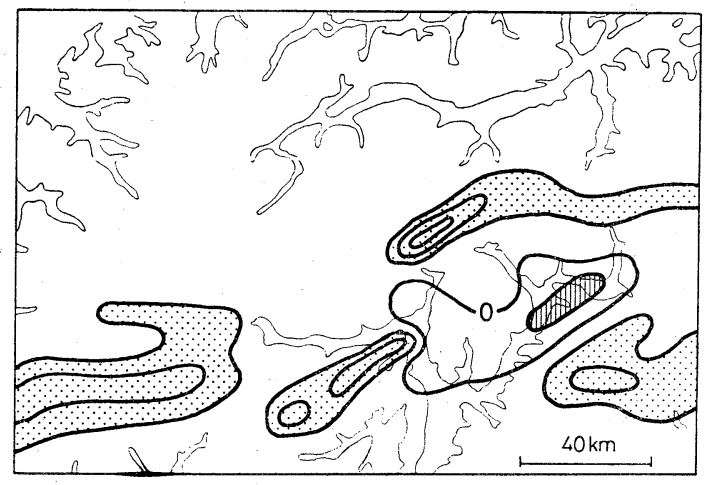

(a)

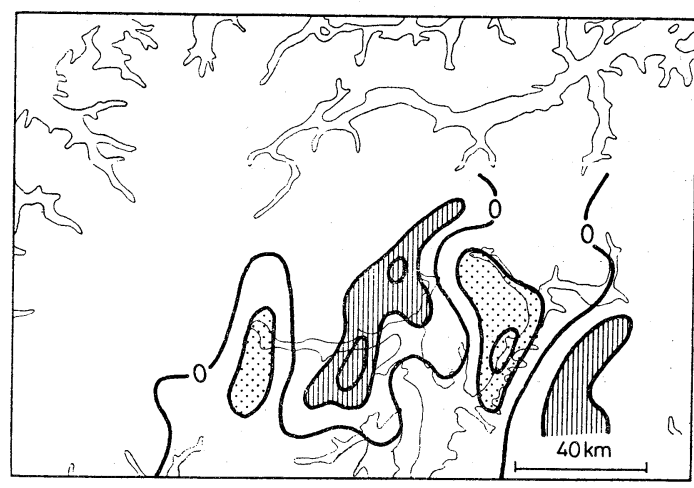

(b)

Figure 10. Meridional (a) and zonal (b) gradients of precipitation frequency in the case of Type III. Hatched pattern indicates increase of frequency from south to north in meridional component (a) and from west to east in zonal component (b). Dotted pattern indicates decrease of frequency in both component.

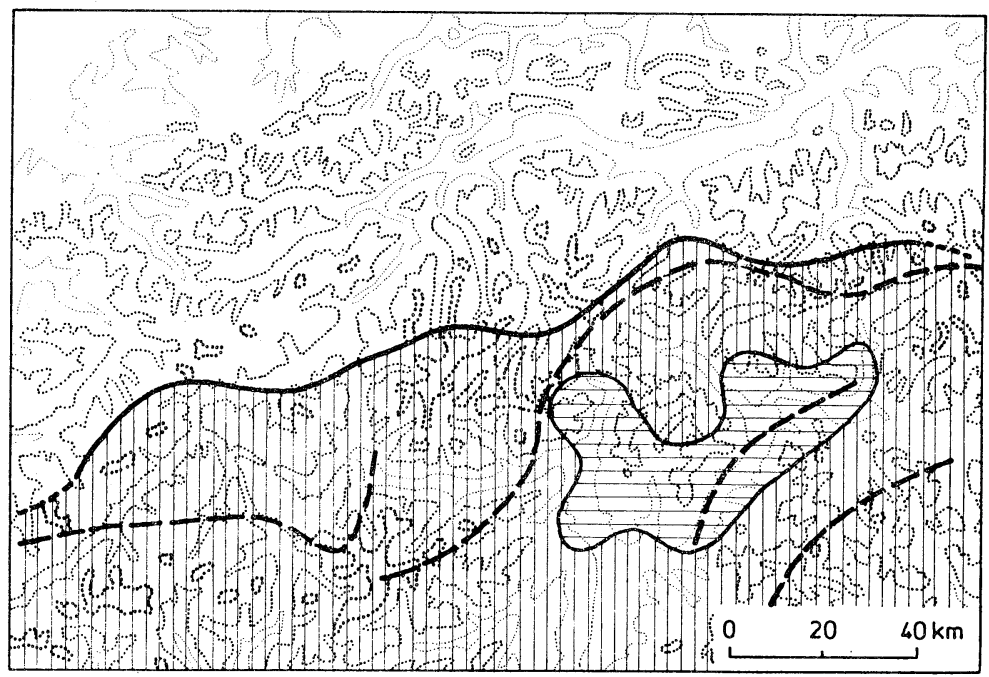

Figure 11. Regional division by orographic effects in the case of Type III. Same as in Figure 8, except in the case of Type III.

was made as shown in Figure 11. On the windward region of the weather divide, remarkable topographic control can be recognized; the rain shadow effect is prevalent, on the whole. In particular, axis of the maximum rain shadow effect runs parallel with the weather divide from the eastern part of Ötztal Alps to Zillertal Alps through Stubai Alps. This shows that the main watershed gives different effects on the distribution of weather and precipitation amount in the case of Types I and III. The weather divide is the border between the weather with and without precipitation in the case of Type I. In the case of Type III, it is not only the border of the weather but also the discontinuity of precipitation amount.

In the south of the main watershed, the blocked effect is also recognized on the windward slopes of Sarntal Alps and in the drainage basin of the upper stream Eisack. This suggests that the prevailing southerlies go up along the Etschtal and are blocked here. In contrast with the case of Type I, the areas where the precipitation distribution are affected by mountains or valleys, such as Ortler group or Etschtal, tend to elongate in the direction of the prevailing wind aloft; the lines of the maximum effects of orography tend to run from the slopes of Ortler group and Etschtal 
to along upper wind directions. In addition to this, the band like distribution of precipitation appears frequently along Etschtal and also along the southeast slopes of Ötztal Alps and Stubai Alps. This tendency becomes more distinguished in Type IV.

2) Formation of rain band

Band like structure of precipitation distribution appears frequently in the cases of Types IV and III. In particular, rain band becomes clear on the occasion of heavy rain and has a tendency to occur at fixed locations. This suggests the orographic influence on the formation of the rain band as pointed out by Aoy Ama (1984). In order to examine this orographic effect, twenty three cases of heavy rain days were selected in the years of 1948 to 1957 on the basis of the same data described before. The heavy rain day was defined as the days in which the precipitation above $100 \mathrm{~mm} /$ day were observed in the study area. These precipitation distribution maps were classified into four types, Types I, II, III and IV. For Types III and IV, the geographical frequency distributions of precipitation above $50 \mathrm{~mm}$ were made by setting the same grids described before. In Figure 12, the frequency of precipitation above $50 \mathrm{~mm} /$ day and the axes of rain bands are shown.

On the whole, the feature of frequency dis- tribution is almost the same as that of Type IV. However, band structure of frequency distribution running meridionally along the valleys of Etschtal and Wipptal is a very conspicuous character. The axes of the rain bands also tend to concentrate in these valleys and to coincide with this maximum frequency. In particular, the axes of rain bands tend to begin on the western slopes of the Etschtal and Passeiertal, or the eastern slopes of the Ortler group, Ötztal Alps and Stubai Alps in other words, and run toward the NE along the direction of upper prevailing winds which blow along the direction of the valley.

On the basis of the geographical distributions of occurrence frequency of precipitation, the orographic effects were examined. In Type I, the northern side of the Nordtirol Kalkalps makes the border between the blocked and the rain shadow effect and the line of the southern ridges overlap with that of the maximum rain shadow effect. In the case of Type III, the rain shadow effect prevail over almost the whole region except the windward slopes of Sarntal Alps and in front of the Etschtal. This suggests that the prevailing winds blow up along the Etschtal and are blocked by these slopes.

The band like structure of precipitation distribution tends to occur frequently at fixed

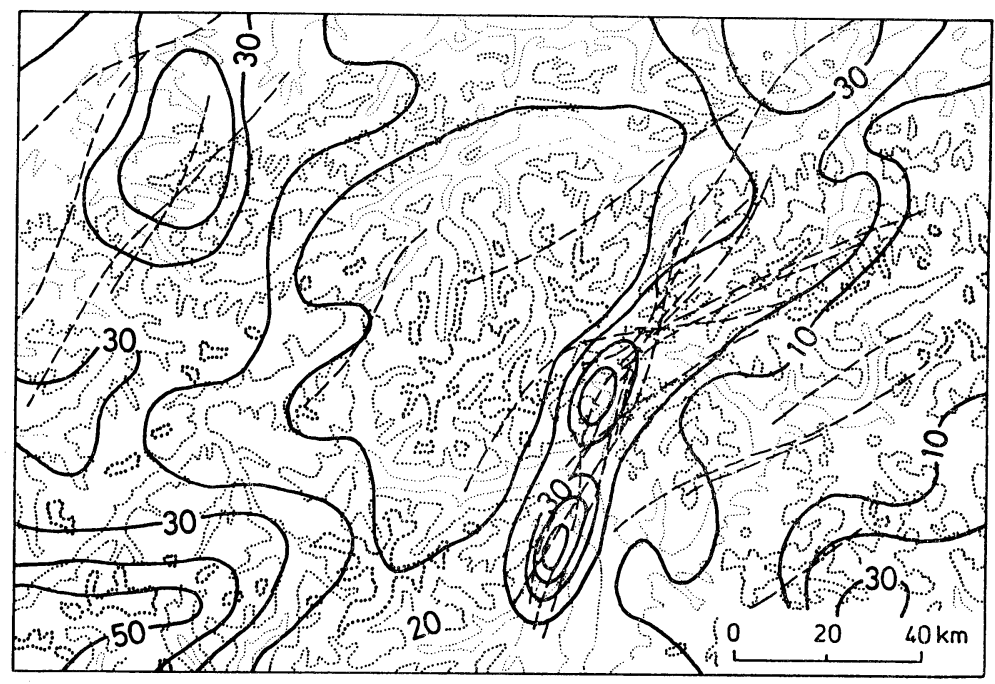

Figure 12. The percentage frequency of the days with daily precipitation more than $50 \mathrm{~mm}$ and the axes of rain band (dashed lines) in the case of Type III and Type IV. 
locations in the cases of heavy rain in Type IV and also in Type III. The axes of the rain band concentrate in the valleys of Etschtal, Passaiertal and Wipptal; the axes run from the eastern slopes of Ortler group, Ötztal Alps and Stubai Alps toward NE along the direction of the prevailing winds.

\section{Conclusion}

The meteorological conditions accounting for the occurrence of the precipitation distribution pattern and the orographic effects were examined on the bases of the daily precipitation maps in Tirol.

The distribution of the precipitation amount were classified into four main types. These are the north blocked type (Type I), the south blocked type (Type III), the transitional type (Type II) between Type I and Type III and the whole-area rain type (Type IV). Apparently, the orographic effects can be recognized through these precipitation patterns. That is, the blocked effect and rain shadow effect are clearly shown in Type $I$ and Type III. In addition to these effects, the orographic rain bands appear frequently in Type IV and also in Type III.

These types of rain pattern occur under the characteristic synoptic conditions. Type I occurs in the convectively stable stratification under the upper wind direction of NW quadrant. Type III occurs in intermediate stability between those in Types I and IV and wind aloft is southwesterly or southerly. Type IV appears under the condition of the most unstable stratification and the wind aloft is the direction of WSW or W in the cases of Types IVa and IVc and SSW in Type IVb. These results demonstrate that the blocked and the rain shadow effects become significant and the rain area is blocked by the main watershed in the relatively stable stratification under the upper wind direction of the large north or south component. It was also pointed out that the effect to make orographic rain band become clear under the unstable condition.

The geographical distribution of the blocked and rain shadow effects were investigated on the basis of the precipitation frequency of
Type I and Type III. The results are shown in Figure 8 and 11. In the case of Type $\mathrm{I}$, the blocked effect is conspicuous on the northern slopes and the rain shadow effect predominates on the southernside of the northern Alps. In the case of Type III, the rain shadow effect dominates in the southern side of the main watershed of this study area except on the windward slopes of Sarntal Alps and Etschtal. This suggests the prevailing southerlies go up along the Etschtal and are blocked here.

The band like structure of precipitation distribution are frequently recognized in Types III and IV. The axes of the rain band and the precipitation frequency above $50 \mathrm{~mm} /$ day are indicated in Figure 12. The axes concentrate in the region along the valley of Etschtal and Wipptal; they begin to form on the western slopes of Etschtal and Passeiertal and run toward the NE along the direction of prevailing wind aloft.

\section{Acknowledgments}

The author would like to express sincere thanks to Prof. Dr. Franz FliRI, Institute of Geography, University of Innsbruck, for his helpful suggestions and encouragements. The author is also indebted to the staff members of the Institute of Geography, University of Innsbruck, for their kind help in many ways.

(Received May 27, 1985)

(Accepted August 14, 1985)

\section{Notes}

1) This blocked type represents "Stau Type" in German. "Stau" effect refers to one of the windward effects of orography.

2) The original classification of weather situations was presented by LAuscher (1954).

3) A wind which is called "Bise" blows from north or northeast in the Alps region of France and Switzerland. It is defined here as weather situation of easterly at the surface and the upperlevel.

4) The English expression of these weather situations follows BARRY and PERRY (1973).

\section{References}

Aoyama, T. (1984): Synoptic climatological study of precipitation distribution in the Kanto district, central Japan. Geographical Reports of Tokyo 
Metropolitan University, No. 19, 99-112.

Aoyama, T. (1985): Synoptic climatological studies of weather divide in Tyrol, Austria. Wetter und Leben, 36, 181-194.

BArry, R.G. and Perry, A.H. (1973): Synoptic climatology, methods and applications. Methuen \& Co. Ltd., London, 555p.

FLIRI, F. (1967): Über die Klimatologische Bedeutung der Kondensations Höhe im Gebirge. Die Erde, 98, 203-210.

FLIRI, F. (1969): Klimatographie der Tirol-autobahn. In Festschrift für F. Huter, Tiroler Wirtschaftsstudien, Nr. 26, Univ.-Verlag Wagner, Innsbruck, 99-122.

FLIRI, F. (1974a): Niederschlag und Lufttemperatur im Alpenraum. Wissenschaftiche Alpenvereinshefte Ht. 24, Innsbruck, 111S.

Fliri, F. (1974b): Die Alpen als Klimascheide: Vorstellungen und Wirklichkeit. Bonner Meteorologische Abhandlung, 17, 417-426.

FliRI, F. (1982): Klima, Tivol Atlas. Univ.-Verlag Wagner, 26S.

FLIRI, F. (1983): Die Niederschlagverteilung in den Alpen an Tagen mit starkem Südföhn in Innsbruck und in Altdorf. Wetter und Leben, 35, 154-162.

FloHN, H. (1954): Witterung und Klima in Mitteleuropa. Forschungen zur deutschen Landeskunde,
78. Zürich, $214 \mathrm{~S}$.

Kawamura, T. (1961): The synoptic climatological consideration on the winter precipitation in Hokkaido. Chirigaku Hyoron (Geographical Review of Japan), 34, 583-595. (in Japanese with English abstract).

KaWamura, T. (1964): The synoptic climatology of winter monsoon in Japan. Chirigaku Hyoron (Geographical Review of Japan), 37, 64-78. (in Japanese with English abstract)

Lauscher, F. (1954): Dynamische Klimaskizze von Österreich. In FLOHN, H.: Witterung und Klima in Mitteleuropa. Forschungen zur deutschen Landeskunde 78, Zürich, 145-158.

WAGNER, M. (1964): Die Niederschlagverhältnisse in Baden-Würtemberg im Lichte der dynamische Klimatologie. Forschungen zur deutschen Landeskunde, 135, $119 \mathrm{~S}$.

\section{Data}

Ackermann, P. $(1956,1957)$ : Klima der freien Atmosphäre, Aerologische Station Payerne, Annalen dev Schweizerischen Meteorologischen Zentralanstalt, $\mathrm{Nr}$. 6, Zürich.

SchÜEPP, M. and HÄFELIN, J. (1956, 1957): Wetterlagen und Fronten. Annalen der Schweizerischen Meteorologischen Zentralanstalt, Nr. 7, Zürich.

\section{チロル地方の降水量分布に関わる山岳の影響について}

青山高 義*

チロル地方の日降水量分布型とそれに関わる気象条件 を整理しささらに山岳の影響について考察した。まず 1956年と1957年の日降水量分布㘠 250 枚を，4つの分布 型（I, II, III, IV 型）に分類した. 各分布図に $10 \mathrm{~km} \times$ $10 \mathrm{~km}$ のメッシュをかケ, 日降水量 $10 \mathrm{~mm}$ 以上の頻度 分布を各降水量分布型ごとに求めた。 そ机ぞれの頻度分 布図は地形の影響を明瞭に示して扣り，I 型は北方せき 止め型, III 型は南方せき止め型, 又はフェーン型, II 型 はI 型と III 型の漸移型，IV 型は全域型である。な招 III 型とVI 型では, しばしばレインバンドを伴う.

次に, 各降水量分布型出現時の天候型, 上層風向, 対 流不安定について検討した. I 型, III 型は上層風型沉天 候のもとに発生し，I 型は上層風向 $\mathrm{NW} \sim \mathrm{N}$ で安定な成 層状態，III 型では上層風向 $\mathrm{SW} \sim \mathrm{S}$ で相対的に不安定な 成層状態の中で発生する傾向がある.IV 型は上層風向が
南寄りであるが，III 型より西成分が大きく，大気は最も 不安定である.

日降水量分布には, I 型と III 型で山岳のせき止め効 果と雨陰効果が認められ，III 型とIV 型ではこれ等の作 用に加えて特定地域にレインバンドを形成する作用など が認められる. そこで, これ等の山岳の影響を先に示し た降水頻度分布図に基づいて調べた．地形の影響を隣り 合らメッシュ間の頻度差で表せると考え, 卓越風向に 沿って頻度が増加する場合をせき止め効果, 減少する場 合を雨陰効果としてその分布を求めた. 以上の結果に天 気界の出現位置 (AOYAMA，1985）を考慮して，せき止め 効果, 雨陰効果による地域区分を I 型 (第 5 図) と IV 型 （第6図）について行った。 またレインバンドについて は，1948～1957年の III 型，IV 型に分類される大雨日の 多雨軸分布を示した（第 7 図). 